\title{
SOME CURRENT TRENDS IN PALYNOLOGY
}

\author{
A. A. MANTEN \\ Secretary, International Palynological Committee, Cortezlaan 9, Utrecht (The Netherlands)
}

\section{SUMMARY}

A number of modern developments in palynology are reviewed, with emphasis on those subjects which may be of interest and, possibly, also of practical value to geologists of various specializations. These include pollen preservation, the use of accumulation-rate diagrams as opposed to the classical pollen-percentage diagrams and the application of fluorescence microscopy. Marine palynology is discussed in a rather detailed fashion and its various prospects for stratigraphy, sedimentology and environmental geology are outlined. Some trends in preQuaternary palynology include new attempts at a palyno-stratigraphy of the Neogene, the many applications of palynological studies of salt deposits, the growing importance of palynology to palaeogeography, palaeoclimatology and palaeoecology, and the use of a decimal code system for microfossils. Palynological data about the origin of the gymnosperms, chlamydosperms and angiosperms are briefly summarized. General information is presented about microphytoplankton evolution in the course of geological time.

\section{INTRODUCTION}

In a limited amount of space, it is impossible to review, even in large outlines, all the work that has been carried out by palynologists in the most recent years. Certain limits must be established. The first will obviously be a restriction to the more geological aspects of the subject, leaving recent progress in such subjects as pollen morphology, allergy research and melittopalynology aside. How these branches fit within the total framework of palynology has already been indicated in the historical review (MANTEN, 1966b). A further selection may be made by particularly stressing subjects which may be expected to be of interest and, possibly, also of practical value to geologists of other specializations.

As there is no need to duplicate what has already been reviewed in other contributions to this journal, a few subjects can safely be omitted from this paper. Thus, a review of microfossils, generally of botanical affinity, which were found in Precambrian deposits, has recently been written by GLaESSNER (1966), and 
the research regarding microfossil-like objects in meteorites was briefly summarized by the present author (MANTEN, 1966a). A number of current trends have also been briefly indicated in the historical review which precedes this article (MANTEN, 1966b).

\section{POLLEN PRESERVATION}

It is a well-known fact that the composition of a fossil pollen-and-spore assemblage does not actually reflect the composition of the vegetation in the area in which and at the time during which the fossil assemblage was deposited. Main disturbing factors are differences in pollen production between the various plant species, differences in pollen dispersal, variations in rate and manner of sedimentation, and differences in preservation.

The first three of these factors have been the subjects of many studies. However, the study of pollen preservation has long remained neglected. One of the first to devote attention to this problem was KirchHEIMER (1933a,b, 1934, 1935), who observed that pollen grains and spores found in lignites apparently differed in their resistance to oxidation. In recent years, the study of pollen preservation has been resumed by, among others, HavingA $(1962,1964,1967)$, Cushing (1967) and WiLson (1961, 1967).

The primary reason for the scant amount of attention paid to pollen-and-spore preservation for such a long time may have been that during the period in which pollen analysis was mainly applied to sediments such as gyttja, dy or peat, good preservation was generally assumed to be self-evident (HAviNGA, 1967). When, during the last decades, pollen analysis was extended to nearly every kind of sediment (in several of which pollen corrosion is much more severe), palynologists had developed a "blind eye" for this aspect of their subject and "recovery" went very slowly.

There are two fundamentally different approaches to the problem of pollen preservation. One is to experimentally subject pollen to controlled laboratory or field environments. The other is to collect data about the preservation of pollen already present in a variety of sediment types and to generalize from these data.

In order to improve communication about pollen preservation, some kind of common terminology is needed. To this end, it is useful to summarize herewith the classes of pollen-and-spore preservation defined by CusHING (1967). Rearranged, these classes are as follows:

(1) Well-preserved.

(2) Broken: Exine very distinctly ruptured.

(3) Crumpled: Grains folded in one or several planes or so twisted or distorted that reconstruction of the original shape of the grain and the orientation 
of the features on the grain are difficult. Cushing subdivides this class into two, based on presence or absence of a noticeable thinning of the exine, but admits that this is highly subjective. When the exines of crumpled grains appear to be thinner than the exine of normal grains of the same type, structural elements seem to be unaffected and the loss of material, if any, is perhaps confined to the endexine. Moreover, exine thinning is prevalent among pollen types with normally thin exines and is thus difficult to measure.

(4) Corroded: The exines are affected by a distinctive etching or pitting. Corroded spots usually appear to be scattered at random on the surface of the grain, and the edges of the pits are often scalloped. Typically, the corrosion only affects the ectexine of pollen grains or the outer layer of a spore wall.

(5) Degraded: The exines appear to have undergone a structural rearrangement, so that sculptural and structural details are resolved only with difficulty. Structural elements appear to be partially fused, but major features, such as apertures, remain recognizable. Almost always, the entire exine of a grain is equally affected. In extreme cases, the pollen wall becomes completely amorphous, making the distinction from other organic particles very difficult.

Pollen preservation may be influenced by various forces, such as microbial attack, chemical oxidation, mechanical forces, high temperatures and coalification. The effect of each of these forces may be different between different sites. Thus, ANDERSEN (1967) found that the ability to resist attack decreased for pollen grains in recent surface samples from Draved forest (Jutland, Denmark) in about the following sequence: Fraxinus-Quercus-Betula-Tilia-Fagus-Alnus-Corylus, whereas VAN ZEIST (1967), in studies of pollen spectra from burial mounds in The Netherlands, found that Quercus pollen appeared to be more susceptible to corrosion than Tilia pollen, whereas Alnus pollen was found to be more resistant. For a detailed discussion of the various factors affecting pollen preservation, readers are referred to HAVINGA (1967).

An aspect of the problem which also needs to be mentioned here is the difference in identifiability between different pollen and spore species in a comparable state of preservation. Thus, Tilia pollen is an example of a kind of pollen which can be easily recognized even in a poor state of preservation. In some cases, this may lead to somewhat exaggerated Tilia-pollen values.

With older palynomorphs, particularly coalification had an important effect on their preservation. As WILSON (1961) and GUTJAHR (1966) pointed out, palyno-stratigraphical and palaeoecological work may become very difficult when palynomorphs are coalified so intensely that they have become opaque and have lost their structures. Therefore, it is important for palynological work on ancient basins to know the rank of coal in order to select favourable areas for palynological type sections.

WILSON $(1964,1967)$ also pointed out that strong coalification and corrosion 
at erosional surfaces exert a selective action on various forms of pollen grains and spores.

\section{PERCENTAGE DIAGRAMS VERSUS ACCUMULATION-RATE DIAGRAMS}

An essential element in the development of each science is that from time to time the principles on which the science is based be reconsidered.

In this respect a fundamental question in palaeopalynology is whether the manner chosen to express the abundance of the various types of pollen grains and spores really was and still is the best one. The occurrence of various species or other taxa is almost always given as a percentage of the total microflora or of some selected portion of it, called the pollen sum. The difficulty in this procedure is that these percentages exaggerate differences between specific concentrations: even though a certain species remains constant in absolute concentration, it will decline in percentage if the amount of another species increases. VON POsT (1916) was already well aware of this problem. However, he felt it important that the values obtained were at least independent of the types of peat in which the pollen grains and spores were found preserved. This was not true of alternative methods of presentation of pollen-analytical data, such as absolute numbers of pollen grains per unit volume or weight of peat. Von Post suggested that there might be an advantage in using absolute pollen frequency, but saw no possibility to develop a reliable method, since relative accumulation rates of peat types could not be estimated at that time.

The idea of determining absolute pollen frequencies was recently revived by, among others, Traverse and Ginsburg (1966) and Davis (1967). The discovery of radiometric methods for determining ages of sedimentary deposits now makes it possible to estimate absolute rates of accumulation of the various kinds of sediments, which are known to be quite variable. Dividing the concentration of pollen per gram of sample by the established accumulation rate could thus produce an alternative figure for the expression of pollen frequency.

The first results obtained by DAVIS (1967), however, make it questionable whether such an expensive and laborious method is, after all, greatly advantageous (except in special cases) as compared to the classical method using percentages. An example of such a case is Late Glacial pollen sequences, many of which record vegetations which changed considerably in pollen productivity as tundra was replaced by park tundra and woodland, and woodland was replaced by forest. As a result, in such sequences the changes in pollen percentages from one level to another are distorted and cannot indicate directly the direction of vegetation change.

Pollen-accumulation-rate diagrams, however, do not yet show truly absolute pollen frequencies. They do not yield population counts for the various tree 
genera, since deposition rates cannot be related to numbers of trees. TAUBER (1965), for instance, showed that the number of pollen grains entering a lake per unit area probably varies with the size of the lake. It may even be questioned whether the deposition rate at the point where the core was taken is proportional to the total pollen input to a lake, rather than dependent upon local, and possibly varying, conditions of sedimentation (DAvIS, 1967).

Thus, pollen-accumulation-rate diagrams will in the future probably be used in addition to the classical percentage diagrams, but certainly not instead of these. The overall alternative to the latter, if it could be found, has not yet been discovered.

\section{FLUORESCENCE PALYNOLOGY}

A very promising direction which has been developing in palaeopalynology since 1960 , is the use of fluorescence microscopy.

Almost all fossil palynomorphs have been found to be fluorescent; exceptions are encountered only in some cases of strong coalification or bad preservation. The fluorescence is based on the property of organic substances to transform short-waved ultraviolet light into light of the visible range of the spectrum. A distinction has to be made between primary fluorescence (or autofluorescence) and secondary fluorescence. The latter is based on specific staining methods under the microscope and is widely used in biological and medical work. For palaeopalynological research autofluorescence is the most important.

The first palynological applications of fluorescence microscopy were made by allergologists, already well before World War II, when they were searching for pollen grains and spores causing hay fever (BERGER, 1934).

The first observations of fossil palynomorphs under ultraviolet light were not made, however, before 1958, when MaIER and Wetzel studied slides of organic sediments from Germany and noted the luminescence of some microfossils, e.g., Hystrichosphaeridae. Remarkably enough, they overlooked the fluorescence of pollen grains, spores and other botanical remains as occurring in slides of hardrock and lignite, and even stated by repetition that only animal fossils show luminescence colours (MAIER and WeTZEL, 1958; MAIER, 1959; WETZEL, 1959). It has been VAN GIJZEL $(1961,1963,1966,1967 \mathrm{a}, \mathrm{b})$ in particular who has shown that fossil pollen grains and spores also fluoresce under ultraviolet light, and that this phenomenon can be used taxonomically and geochronologically.

The late discovery by the palaeopalynologists of the value of fluorescence microscopy may have been influenced by the fact that in so many cases conventional pollen analysis led to good results (VAN GIJZEL, 1967a).

Four aspects of fluorescence palynology can be distinguished: 
(1) Fossil pollen grains and spores of different taxonomic position (but of the same geological age) show different, more or less characteristic fluorescence colours.

(2) With increasing geological age all fossil palynomorphs show a change in fluorescence colour from the bluish-green towards the orangish-red part of the spectrum (in the Holocene, fluorescence colours are bright; in the Pleistocene, yellowish colours begin to increase in importance at the cost of bluish and greenish colours; in the Tertiary, the blue and green disappeare gradually, being replaced mainly by yellow, and vesiculate palynomorphs show for the first time orangish colours; in the Mesozoic, yellow, orange and brown become dominant; in the Palaeozoic, fluorescence finally disappears).

(3) With increasing geological age, the total intensity of fluorescence also decreases gradually, but less regularly than changes in colour.

(4) With increasing coalification, palynomorphs change in fluorescence colour from greenish-yellow towards orangish-red, followed finally by complete extinction.

Important palaeopalynological applications of fluorescence palynology include:

(1) Age determinations of deposits of unknown age, particularly Cenozoic deposits, by comparing fluorescence with a standard diagram of fluorescence set against geological age. In this way, age determinations can be made with an accuracy of over $80 \%$ (VAN GIJZEL, 1967b).

(2) Long-distance correlation.

(3) Distinction between autochthonous and reworked palynomorphs.

(4) More rapid and easier detection and counting of palynomorphs in slides very poor in botanical microfossils.

(5) Determination of the rank of coal.

\section{MARINE PALYNOLOGY}

A most important recent development is the application of palynology in the study of ocean areas. This started gradually in the nineteen-fifties and is now expanding rapidly. It offers a promising approach to the study of Cenozoic stratigraphy in ocean basins and to obtaining a relatively continuous record of major vegetational and climatic changes over a considerable span of time. In addition, it is the only universal method by which marine sediments, including those of abyssal facies, can be correlated with continental sediments. Marine palynology may provide data where other methods for determining stratigraphic zones fail. 


\section{Survey of contributions to marine palynology}

The first paper describing pollen-analytical studies of marine bottom sediments and cores seems to be the study by LARSSON (1948) of 87 samples and 3 cores from the Tyrrhenian Sea. It was not until the second half of the nineteen-fifties that further similar studies were undertaken and, by far, most of the information now available dates from the last five years. Particularly noteworthy is MULLER's (1959) analysis of the origin, distribution and sedimentation of pollen grains, spores, tracheids, cuticles, fungi, dinoflagellates, hystrichospheres and microforaminifera found in sediments of the Orinoco delta, the Gulf of Paria, and surrounding areas. His attempt to relate these in part to source vegetation, to some of the features of wind and water currents, and to several geological and oceanographical aspects of sedimentation and environment, is a landmark in the rise of marine palynological research (Cross et al., 1966). Further studies were undertaken in the estuary of the Delaware River (GROOT, 1966), off the eastern coast of the U.S.A. (STanley, 1965b), the Bahamas (Traverse and Ginsburg, 1966, 1967), in the southwestern Atlantic Ocean (Groot and Groot, 1964, 1966b; Groot et al., in press; STANLeY, 1967), the northwestern Atlantic Ocean (StANLEY, 1966a), on the Biscay Abyssal Plain (Groot, 1963), in the North Sea (ZAGWIJN and Veenstra, 1966), the Baltic Sea (Lubliner-MianowsKa, 1962), the Mediterranean (Rossignol, 1961, 1962; Vronskiy and Panov, 1963; Koreneva, 1966), the Adriatic Sea (Bottema and Van Straaten, 1966), the Black Sea (Neustadt et al., 1965), the Sea of Azov (Panov et al., 1964), the South China Sea (Van Veen, 1958), the Japanese Sea (Koreneva, 1961; Boulouard and Delauze, 1966), the Sea of Okhotsk (Koreneva, 1957), the western Pacific Ocean (Koreneva, 1964), the Gulf of California (Cross et al., 1966) and off the coast of central Chile (Groor and Groot, 1966b, in preparation).

\section{Pollen transport to the oceans}

Pollen grains and spores reach marine areas mainly in two ways: by wind or by water. It is understandable that the former dispersal medium was studied much earlier than the latter, also where ocean areas were concerned.

As early as 1919, HesSELMANN showed that pollen grains and spores can be transported by wind over great distances. He exposed plates to trap pollen on two lightships in the Gulf of Bothnia. On one ship, situated $30 \mathrm{~km}$ (19 miles) offshore, 103,037 pollen grains were trapped in slightly more than one month. In the same interval, 56,075 grains were trapped on another ship, $55 \mathrm{~km}$ ( 34 miles) offshore. These figures correspond to 1,620 and 880 grains $/ 1 \mathrm{~cm}^{2} / 34$ days.

ERDTMAN (1954) reported that in a sample collected from southwestern Greenland, 28,000 pollen grains were found, of which 355 were conifer pollen grains. Some of the conifers which provided these pollen grains were not native 
to Greenland. Erdtman assumed that these grains had been carried by wind from the North American continent, over a horizontal distance of $1,000 \mathrm{~km}$ or more.

In the textbook quoted above, Erdtman also mentioned the results of his well-known experiment in which he used a vacuum cleaner to trap pollen during a voyage from Gothenburg to New York, in order to estimate the absolute number of pollen grains transported by winds across the Atlantic Ocean. He found, at that time, that the number of pollen grains and spores per $100 \mathrm{~m}^{3}$ of air declined from 18 in the North Sea to 0.7 in the middle of the Atlantic Ocean; rose to 6 off Newfoundland; fell to 3.5 south of Nova Scotia; and finally rose to 15 off the coast of New England. As a contrast it should be stated that Erdtman found 18,000 pollen grains per $0.25 \mathrm{~m}^{3}$ ( 9 cubic feet) $110 \mathrm{~km}$ west of Stockholm.

Earlier, the same author (ErdtMan, 1943) and Dyakowska (1948) had shown that at least $90 \%$ of the pollen grains transported in the atmosphere were deposited in the ocean within about $100 \mathrm{~km}$ from the shore. The greatest quantities were deposited long before this distance had been reached (FAEGRI and IVERSEN, 1964).

It was particularly MuLLeR (1959), who demonstrated that transportation of pollen grains and spores by water is often more important than wind transport when explaining certain distributional phenomena in Recent marine sediments. In deltaic and shallow-marine deposits, certain types of pollen grains and spores may be preserved within, or comparatively near, the environment that favoured the growth of the supplying plants. These are important as indicators of sedimentary environments. Many other pollen grains and spores, however, are brought down by rivers; sometimes over long distances. Fedorova (1952) observed pollen transport over 1,400 km in the Volga River. Rossignol (1961), who studied sediments off the coast of Israel, found that many pollen grains and spores were transported by the Nile, and subsequently by currents along the coast. In analyzing marine-sediment samples, this long-distance water transport should be taken into account in order to prevent false palaeoecological and stratigraphical conclusions. Groot (1966) showed that in the estuary of the Delaware River a relationship exists between the number of pollen grains and the quantity of mineral matter in suspension, suggesting that the two types of particles are predominantly transported together and in similar fashion. Earlier, Soviet researchers (KoRENEva, 1957, 1964; PANOv et al., 1964), had already demonstrated that the quantities of pollen grains and spores found in Recent marine deposits were related to the grainsize distribution of the sediment; coarse-grained sand containing less palynomorphs than muds of fine clay.

\section{Abundance of pollen grains and spores in water}

Enormous variation has been found in the number of pollen grains and spores per 1001 of water. For the Delaware River estuary, Groot (1966) found values 
ranging from 50,000 to 800,000 , with a tendency to decrease toward the lower part of the estuary. Several authors observed that in sea water and also in marine sediments, the highest concentrations are found near the mouth of rivers. TRAVERSE and Ginsburg (1966) mention the following average figures: 90,000 for Trinity River, Texas, near its mouth; 8,000 for the Gulf of Mexico near Galveston, Texas; and about 1,000 for the waters around the Bahama Banks. In the latter area no streams debouch and Traverse and GinsBurg (1967), therefore, initially expected that in that area there might be a relationship between pollen sedimentation, especially that of pollen of wind-pollinating plants, and the wind system. However, they established that the concentration of pine pollen in the water had little, if any, relation to the source of the pollen grains or to aerodynamical factors (except insofar as wind determines the hydrographical features of the Bahama Banks), pollen distribution apparently being related instead to water movements, salinity and turbulence. Also, they found that once delivered to the water, the pollen grains are subjected to the same sedimentary factors as are other particles. As a sensitive indicator of sedimentary patterns, palynology could be a useful tool in sedimentology.

\section{Abundance of pollen grains and spores in marine sediment}

The number of pollen grains and spores per gram of marine sediment also varies extensively, from less than ten up to more than several million. The abundance depends on several factors, such as (1) the type of sediment (most favourable are lutites of terrigenous origin, less favourable are coarse sediments and deposits with a high carbonate content; pollen grains and spores are common in turbidites, but it is still uncertain whether pollen analyses can be profitably applied to such deposits); (2) distance from shore; (3) the nature of the environment of deposition (oxidizing or reducing, or time elapsing between deposition of the pollen grains on the sea floor and the end of its exposure to oxygen by burial under new sediment, transgressive or regressive, saline or brackish, water temperature, etc.); (4) oceanic circulation; (5) the macro- and micro-relief of the ocean floor; (6) meteorological conditions; and (7) the pollen or spore production and dispersal characteristics of the plants.

Quantitatively, the most significant of the above factors seems to be the type of sediment (Groot and Groot, 1966a).

\section{Only generalized pictures}

Sediments from inland seas and marginal seas yield the largest variety of nonreworked pollen grains and spores. Often a general relationship can be found between the composition of the palynological spectra from these seas and the vegetation of the surrounding land. Thus, KorenEva (1957) could distinguish 
four regions in the Sea of Okhotsk, viz. (I) a northern region, which is under the influence of the Beringian shrubby (forest-tundra) vegetation; (2) the Kamchatka region, which is under the influence of a grassy-deciduous forest vegetation; (3) a southwestern region, which is under the influence of a dark coniferous spruce-fir taiga; and (4) a central region with spore-and-pollen spectra of a mixed nature. For the Mediterranean, that author (Koreneva, 1966) found that the general composition of the vegetation in the surrounding land is primarily reflected in the spectra prepared from those samples which are collected relatively close to the coast and which are rich in pollen grains and spores.

It is impossible to reconstruct plant communities from marine-palynological data from deep-sea localities because these pollen spectra may contain palynomorphs from a large to very large area so that local differences are equalized. In the second place, a strong to very strong selection takes place which results in the presence in deep-sea deposits of mainly those spores and pollen grains which because of their structural properties can be transported by water over long distances. Thirdly, most minor, short-time vegetational changes and climatic fluctuation are not reflected, because with the low rates of sedimentation in the deep ocean and the rather large quantities of sediment needed to recover an adequate number of spores and pollen grains, each sample may represent a period of some hundreds or even a thousand years (GROOT and Groot, 1966a).

The deep-sea palynological spectra, however, are very useful in establishing a chronology of major vegetational and climatic changes which took place in a certain part of the earth. Thus, Groot and Groot (1966b) demonstrated, on the basis of pollen spectra from deep-sea-sediment cores in the southwest Atlantic and southeast Pacific Oceans, that central and southern Chile and the Andean region of Argentina have experienced alternating "warm-dry" and "cool-moist" periods throughout the Quaternary. Their conclusion is supported by a carbonate curve similar to that found in the equatorial east Pacific by Arrhenius (1952), who correlated zones of high and low carbonate content with glacial and interglacial stages, respectively.

In general, diagrams from inland and marginal seas can be well-correlated with diagrams from the adjacent land. In some cases, it appeared possible to also correlate a pollen diagram based on deep-sea cores with diagrams from continental sites. Because of the three reasons given above, however, there are also marine diagrams from some areas which reflect the regional vegetation with sufficient disproportion to pose special problems in correlating synchronous marine and terrestrial deposits.

\section{Deep-sea Cenozoic stratigraphy}

The most favourable areas for marine palyno-stratigraphical work, as far as the deep sea is concerned, appear to be oceanic rises and abyssal plains where 
sediments of terrigenous origin are diluted with biogenous material. The oceanic rises have the additional advantage that, there, one escapes the effect of turbidity-current deposition, which is to increase greatly the rate of sediment accumulation, with the result that even the longest cores rarely reach sediment zones older than the last glaciation in basins where turbidity currents have occurred frequently.

A disadvantage of sampling from topographical highs is that in these places, in contrast to the basins, slumping of sediment may have caused the loss of some part of the section. As a rule, such hiatuses are not evident from examination of the lithology. This holds particularly for hiatuses within the Pleistocene part of the section. The only way in which they can be detected is to cross-correlate the pollen diagrams prepared from several cores from the same region. It may, of course, be that slumping has occurred simultaneously on several isolated rises (if triggered by, e.g., a seismic shock), but the probability of loss of the same stratigraphical zone at the various sampling stations becomes very small to nil if the number of cross-correlated cores increases and the geographical scatter of the coring stations widens.

\section{Reworked palynomorphs as a disturbing factor}

A serious difficulty in marine-palynological work, as in other fields of palaeopalynology, is the common occurrence of pollen grains and spores that are reworked (recycled, redeposited) from older deposits. Reworked pollen in streamtransported sediments is frequently a significant element of the total pollen-andspore flora, sometimes as much as $10-25 \%$ or even more. Reworked pollen grains and spores from onshore sites are often present in significant percentages in offshore sedimentary deposits. A further important percentage may consist of reworked fossils freed by underwater erosion of older strata outcropping beneath the sea, either on the continental shelf or on the continental slope. Thus, Groot (1963) found up to $50 \%$ of reworked fossils of Tertiary-Palaeozoic age in Quaternary sediments in the Biscay Abyssal Plain. The other known extreme is the Delaware River and Bay, in which, according to Groor (1966) the amount of reworked material is less than $1 \%$. This is due likely to the tremendous number of modern pollen grains that are transported by the water of that river.

Reworked pollen grains and spores may be easy to distinguish from primary fossils if there is a great difference in age. Thus Mesozoic grains found in a Cenozoic deposit, and especially those in modern sedimentary basins, are morphologically distinct from the Cenozoic pollen grains and spores. They may be more strongly corroded and do not take safranin 0 stain in the same way as the latter do. The latter method is even stated to be useful in distinguishing certain Tertiary pollen grains and spores from Pleistocene and younger plant microfossils (STANLEY, 1966b). On the other hand, it is only with extreme difficulty that it is possible to 
recognize reworked Tertiary pollen in slightly younger beds or, in fact, any pollen grains and spores which are deposited in a second cycle of sedimentation of only slightly younger age than primary deposition. Thus, according to A.T. Cross (personal communication, 1966), Pleistocene and even Pliocene pollen grains, being reworked into modern deposits on both the Atlantic and Gulf Coasts of North America and in the thick sequences in the Gulf of California, are not yet easily distinguished by stain techniques, autofluorescence (VAN GIJZEL, 1961, 1963, 1967), or any other known method. MulLER (1959) had already experienced this difficulty. He found that Pleistocene pollen was very difficult to recognize as such and that the separation of reworked older Holocene pollen from Recent pollen was next to impossible.

\section{Reworked palynomorphs as a source of information}

Reworked pollen grains and spores also have a positive aspect. STANLEY (1966a,b, 1967) found that the percentages of secondary pollen grains and spores compared to the total number of grains encountered (primary plus secondary) were distinctly higher in sediments formed during Recent times. This led him to the hypothesis that the high percentages of reworked pollen grains and spores occurring in sediments deposited during periods of continental glaciation were the result of an increase in erosion brought about by base-level lowering during the glacial periods (STANLEY, 1965a). Orogenic movements can also affect base level, and these movements may be recognizable in Pleistocene and even pre-Pleistocene sediments on the basis of marked increases in the percentages of reworked pollen grains and spores.

Secondary pollen grains and spores also provide a unique way of identifying source areas of marine sediments (STANLEY, 1966b). In addition, reworked pollen grains and spores may provide some information as to the history of the area that supplied the sediment.

\section{SOME TRENDS IN PRE-QUATERNARY PALYNOLOGY}

In the course of the development of palaeopalynology, the main interest has gradually moved from the Quaternary to the pre-Quaternary, and this trend is still perceptibly continuing. It is interesting to note in this respect that at the Second International Conference on Palynology (Utrecht, 1966), 45 papers were presented in the Quaternary section as opposed to 80 in the other palaeopalynological meetings (25 in the Palaeophytic section, 16 in the Mesophytic section, 27 in the section on the Upper Cretaceous and Tertiary, and 12 in the symposia on Chitinozoa and on microplankton of botanical affinity). If we also realize that much more new pre-Quaternary data are not being published than results of work on Quaternary material, it may be assumed that probably $75 \%$ or 
more of present-day palaeopalynological activities concern the pre-Quaternary. Earlier, the author calculated that about $60 \%$ of palaeopalynological literature published during the first half of the nineteen-sixties dealt with the Cenozoic. This is more or less confirmed by the above figures for the Utrecht conference. However, the ratio between Quaternary and Tertiary is distinctly changing in favour of the Tertiary. In pre-Cenozoic research, interests are also continuously becoming more widespread. This is illustrated by the division of the lectures during the Utrecht conference, as given above, and also by the following example.

For several decades the attention of palynologists for the Palaeozoic has been focused mainly on the Permo-Carboniferous. In recent years this has changed significantly. Much work is now done also on other Palaeozoic periods, notably the Devonian. This became also apparent at the Second International Conference on Palynology. Only $28 \%$ of the lectures in the section on the Palaeophytic concerned the Permo-Carboniferous and of the five symposia in this section, the one on the Permo-Carboniferous attracted the lowest average number of attendants.

In the next few pages a few notable developments in modern pre-Quaternary palynology will be briefly described.

\section{Palyno-stratigraphical subdivisions of the Neogene}

In the study of the stratigraphy of Tertiary deposits, palynology initially appeared to be an important aid, particularly in the subdivision of the Palaeogene. A palynostratigraphy of the Neogene was more difficult to establish. This was caused mainly by the fact that in the Late Tertiary less phylogenetic developments took place. Mainly, these had ended at the beginning of the Late Oligocene. In pollen spectra from the Upper Oligocene to the end of the Miocene generally the same genera and species of palynomorphs occur. Quantitative differences between Miocene pollen spectra from various localities were, for a long time, explained mainly by local or regional facies differences. In the Pliocene the deterioration of the climate caused the disappearance of essential elements of the flora.

Palyno-stratigraphical studies of the Neogene were given new impetus when macropalaeobotanical (MAI, 1964, 1965) and sedimentological and geomorphological (LEVELT, 1965) studies revealed that the climate during the Miocene was characterized by a succession of wet and drier periods and that warm and cooler phases cyclically alternated. It appeared that climatic changes could also be recognized palynologically. Thus, SitTLER (1967) demonstrated that in a large part of Europe, a climatic improvement occurred during the Aquitanian. An extensive study of VON DER BRELIE (1967) showed that, at least in central Europe, the time from the Chattian to the Pliocene can be subdivided into seven stages characterized by pollen assemblages distinctly different in their quantitative compositions. The recorded floral changes probably have been caused mainly by climatically induced movements of floral areas. 


\section{Palynology of salt deposits}

Although H. Lueck, in 1913, made mention in his thesis that he had observed winged pollen grains in salt clays in the German Zechstein, it was not until 1950 that salt palynology began to develop. Pioneering work has been done particularly by the Austrian W. Klaus. In 1950, he noted that microspores can be found in quantity and well-preserved in both the clays and the pure salts within a saltbearing deposit. The very pure salts contain, on the average, about 10 pollen grains and spores $/ \mathrm{cm}^{3}$ (several samples may be entirely without microfloral remains), whereas the clays may contain up to 50,000 pollen grains and spores $/ \mathrm{cm}^{3}$.

Klaus's discovery was of great scientific and economic importance. The determination of age and correlation of the various salt deposits and also the establishing of a local microstratigraphy for use in the salt-mining industry presented great problems. The absence of animal fossils in these rocks made it impossible to solve these questions by means of zoomicropalaeontological methods. When exploration for petroleum is carried out in an area with salt plugs, in which salt beds of different age occur, palynology is also of great help, since it enables the determination of the depth at which the salt layer corresponding to the petroleum occurrence has been reached. Palaeobotanically, salt palynology is a method to obtain knowledge about the history of vegetation in arid zones.

Most of the work done on salt-bearing deposits thusfar concerned the description and identification of the pollen grains and spores that were found. However, some stratigraphical studies have also been published already. Because the assemblages of botanical microfossils found in salt deposits were not influenced by local shore or swamp vegetations, they are not only useful for regional stratigraphy but also for long-distance correlations. Great caution in drawing stratigraphical conclusions is needed, however, because the easy solubility of salt in water and the mobility of salt under high pressure make a reworking of palynomorphs possible, e.g., at the margins of a salt plug, and not only from older but also from younger strata.

It is interesting to see that the palynological studies of salt-bearing sediments confirm the discovery that in a large part of Europe, the Upper Permian deposits contain rather similar palynological assemblages. Apart from local differences, the microfforas occurring in the German Basin and in the Alpine regions are identical. The same phenomenon has been established for the Lower Triassic. However, the taxonomic composition of the Triassic microflora is thoroughly different from that of the Upper Permian. The extensive geographical similarities in the European microflora during the Permian and Triassic indicate the existence of an important palaeo-phytogeographical unit.

Contributions to salt palynology have thusfar been made by, among others, KirChHeimer (1950), Klaus (1953a,b, 1954, 1955, 1958, 1960, 1963a,b, 1964, 1965a,b), Potonié and Klaus (1954), Leschik (1956), Jux (1961), Shaffer 
(1961, 1964), Abramova and Marchenko (1964a,b,c), Freudenthal (1964), VARENCOV et al. (1964), VissChER (1966), and BALTES (1967).

\section{Palynologically defined stratotype}

Stratotypes for the various stratigraphic units have thusfar been defined on the basis of their contents in animal fossils or plant macrofossils. Most interesting, therefore, is a recent attempt by ALPERN et al. (1967) to look for a continental stratotype for the Westphalian D in the Lorraine coalfield and to define this with the aid of palynological data.

\section{Palynology and environmental geology}

It should be clear that palaeopalynology has all the potentialities to contribute largely to a further advancement of environmental geology. Although it is not possible to discuss this at length here, at least a brief evaluation of the palynological contribution and some exemplary results will be presented.

One of the first difficulties with which environmental palaeopalynology was faced is that not enough is known about the direct relationships between a pollen diagram and a natural vegetation. Most of the ecological conclusions drawn from Quaternary pollen diagrams in the past half century have depended on qualitative, intuitive interpretation of these diagrams and often on an overestimation of climatic conditions. When discussing pollen preservation, it was already pointed out that several disturbing factors prevent quantitative geographical reconstructions of past vegetations. A large number of studies on the pollen production and dispersal of various plants only helped to elucidate some aspects of this complex problem. More promising is the more overall actuopalynological approach chosen in recent years. This led to a large number of studies on the relation of total pollen rain in various areas to the vegetation of these areas. Ultimately these studies can be applied to problems of the past history of the earth. A review of such studies of modern surface samples was recently prepared by WRIGHT (1967) to which readers are referred for further details. Unfortunately studies using recent surface samples can be carried out only in areas where undisturbed vegetation is still present over large distances. In densely populated areas ( $I$ ) man-made "open" areas promote long-distance transport of pollen grains, and (2) the large number of exotic and cultivated plants seriously disturb the interpretation of pollen spectra from surface samples.

Another main handicap, which particularly affected studies on the Lower Tertiary and the pre-Cenozoic, is that little can be said with certainty about the physical requirements and tolerances of the plants which produced the fossil pollen grains and spores. This even applies to pollen grains which show close similarity to pollen grains and spores of present-day plants. Moreover, the number 
of botanical microfossils with possible recent relatives decreases rapidly with increasing geological age. Already in the Paleocene most fossil pollen grains and spores are of unknown botanical relationship.

This handicap can partly be overcome by confronting palynological data with evidence from other fields of research, a method of cross-fertilization characteristic of the development of the group of scientific fields collectively called environmental geology. Thus, distribution patterns of palynomorphs and various other groups of fossils may together produce evidence about palaeo-topographies; and sedimentological studies may help in deciding what fluctuations in a pollen diagram are due to palaeoclimatological conditions, as illustrated by studies on the subdivision of the Neogene, mentioned earlier in this paper.

BUCHER (1964), while stating that the impressive volume of data concerning remanent magnetism, which has been assembled from all parts of the globe, can be explained satisfactorily by polar wandering and continental drift, emphasized that ultimately the proof for these hypotheses must come from the geological and palaeontological record. In this respect palynology has already led to some mutually valuable confrontations. The striking similarity between European pollen-and-spore assemblages of various ages and their contemporaneous North American microfloras supports the idea of continental drift. Palynologically, it seems very unlikely that during the Upper Palaeophytic and the Mesophytic any important barrier existed between the two continents.

Important in this connection are also the studies such as those by SulLivan $(1965,1967)$. He found that the spore assemblages of the Mississippian reflect a regional differentiation into three main floral provinces. When he superimposed the distribution of these three provinces on a map showing palaeolatitudes, reconstructed by measurements of the direction of permanent magnetism in rocks of Carboniferous age, he observed that spore floras of a similar composition everywhere occupy the same latitudinal belt. This suggests a climatic zonation. This disposition of the floral provinces was, moreover, found to be in broad agreement with the palaeoclimatic zones recognized on the basis of other fossil data and on lithological evidence, e.g., the "reef belts" (HILL, 1957) and the "evaporite belt" (LoTZE, 1964).

Another interesting confrontation was recently attempted by VISSCHER (1967). He observed that in the geochronology of short periods of evaporite deposition and the composition of the palynological assemblages of Permian and Triassic age there are striking similarities between Meso-Europe and the Mediterranean part of Europe. On the basis of knowledge at present available, this seems to be in contrast to palaeomagnetic data, of which those obtained in northeastern Italy, southern France and northern Spain differ considerably from those of Meso-Europe. In recent geotectonic considerations this has been attributed to the so-called Tethys twist, which would have caused a westward displacement of Alpine Europe. 
In the examples summarized above, the palaeoenvironmental conclusions that could be drawn are still of a coarse nature. Such studies are no doubt very useful and they should certainly be strongly stimulated. However, the palynological contribution to environmental geology can still be much refined by laborious detailed work on both Recent surface samples and fossil assemblages in combination with various other kinds of scientific information. The great abundance and ubiquity of spores and pollen grains in the fossil record and the fairly constant characteristics of spores and pollen grains for a particular species give palynology great advantages over many other geological disciplines.

\section{Blurred taxa}

A problem which continuously increases is that of the degree of reliability of many published distribution ranges, both palaeogeographically and stratigraphically, of palynomorphs. This subject has recently been clearly formulated again by HUGHES and MoODY-STUART (1967) and only the essentials need, therefore, be given here.

The average palaeopalynological species starts with a morphological concept and some specimens (sometimes even only one or two), often from different horizons. Thereupon, the recorded distribution becomes extended by other authors by attribution, generally without a new circumscription. The name is then used widely in correlation tables and lists, but the stratigraphical value decreases, since the attributions (usually made without access to the original material) are unavoidably less accurate and careful than the original descriptions. It is urgently necessary that something be done about the dangers of an increasing number of publications and of new taxa, and their very diverse standards. More advantage should be taken of the fact that, unlike most macrofossils, palynomorph taxa are generally fossilized in thousands of specimens (though not in each locality). As soon as larger quantities of a certain taxon are found, which originally was based on only one, or a few, specimens, redescriptions should be required. Also, more uniform and exact standards, internationally accepted, should be established for the description of material. In this way, the stratigraphical and palaeogeographical value of palaeopalynology could be considerably increased, to a level higher than that of many other fields of palaeontological research.

\section{Decimal code system for palynomorphs}

A notable development that has taken place during the last decade in petroleum palynology, is the introduction of a decimal code system for the detailed morphological description of pollen grains and spores. Details were revealed by C. Hopping of the B.I.P.M. (Royal Dutch/Shell Group), at the Second International Conference on Palynology (HopPing, 1967). 
Initially, Royal Dutch/Shell palynologists used the morphological system of FAeGri and IVERSEN (1950) and IVERSEN and TroËLs-SMTTH (1950). At that time it was still believed that the number and position of furrows and pores should form the main basis of a morphological classification. In the course of years, however, it appeared essential to extend and modify the system. This led to the devise of a decimal code system in which the details of the shape, apertures, sculpture and structure, etc. are recorded by means of code numbers.

The code used thusfar by the Royal Dutch/Shell palynologists consists of three groups or pairs of digits, e.g., 03.02.01. Of these, the first pair denotes the main group of features that are considered, the second pair denotes the subgroup and the third pair represents the actual feature. Being initially devised for pollen grains only, after six to seven years of application the system had proved itself so useful that it was revised and extended such that it could also be used for spores, chitinozoans, dinoflagellates and acritarchs.

At present, B.I.P.M. palynologists are investigatiging whether the system could be further refined by applying a decimal coding to all palynomorphs, that comprises six main groups: dissociation, symmetry, vertical differentiation, horizontal differentiation, elementary bodies, and detailed features.

It is evident that the decimal code system has several advantages. It makes it much easier to apply modern documentation aids (punched cards, computers) to the synthesis and analysis of palynological data. It takes a neutral position in the still existing controversy between different terminologies and brings the complex, and often poorly defined, terms of the conventional terminologies down to a language that is much easier to understand. It gives similar treatment to "natural" and to "morphological" taxa. It strongly promotes the urgently required uniform accuracy and comparability of description between various investigators, as was argued earlier in this paper.

On the other hand, there are also disadvantages. As long as there is not one universal coding system, it may throw further obstacles in the path of communication between workers in applied and pure palynology, or easily even in that between palynologists of different petroleum companies. Once a certain coding system has been adopted, it is rather difficult to further refine it and even more difficult to switch to another system if continued research might prove this to be desirable. The decimal code also invites negligence in the recording of those properties of palynomorphs that are not incorporated in the list of coded features. It is suitable for routine stratigraphical work, but is not so suitable for studies on such subjects as plant taxonomy, plant evolution, plant palaeoecology, palaeoclimatology, etc.

The best solution, but one that seems to be most difficult to reach, might well be the combined use of one generally accepted conventional terminology and a universal decimal code system.

A major difficulty that has to be overcome, however, is the difference 
which is still growing between the terminology preferred by the pollen morphologists and that used by most palaeopalynologists. The former group is developing a terminology for the finer structure of the exine which can be studied only with the aid of a phase-contrast or even electron microscope. Only with these techniques is it possible to distinguish between different pollen grains which (under a normal microscope) seem to be identical, and to describe their structure in detail. Pollen morphologists are, therefore, generally inclined towards the terminology of ERdTMAN $(1943,1954)$. The terminology of IVERSEN and TROËLS-Sмith (1950) is less suitable for their purposes because it sometimes fails to clarify what belongs to the ectexine and what to the endexine. Also, the application of terminology by FAEGRI and IVERSEN (1950, 2 ed. 1964) has not been consistent. The complicated terminology of Erdtman, on the other hand, is not very suitable for palaeopalynologists since the various strata are not visible in the wall of fossil pollen grains and counts cannot be made under an electron microscope.

\section{PALYNOLOGY AND THE STUDY OF PLANT EVOLUTION}

Many palaeobotanists have been inclined to ignore spores and pollen grains as a source of palaeobotanical information, and to concentrate on the more informative macrofossils. However, because of their occurrence in relatively large numbers and in a wide range of rock types, spores and pollen grains offer a means of checking the evidence from macrofossils.

\section{Origin of the gymnosperms}

A good example is an interesting study by ChaLoner (1967) on the course of early vascular plant evolution. He considers that no evidence is presently available, in either microfossils or macrofossils, to suppose that vascular plants existed before the Silurian. The spore record suggests that a relatively small number of land plants appeared in the Silurian, with a relatively slow increasing diversity through the Devonian. This is coupled with the origin and development of heterospory during the Middle and Late Devonian (ChAloner, 1967). The nearest approach to a seed habit within the Devonian is seen in a Cystosporites tetrad. There is nothing which can be regarded as convincing pollen before the Carboniferous. However, the pollen grains of some of the earliest Carboniferous gymnosperms appear to have germinated via the proximal, triradiate mark (i.e., they were pre-pollen). If found dispersed, they would be indistinguishable from triradiate isospores or microspores. It must, therefore, be accepted that the earliest pollen occurring among dispersed spores, would probably pass unrecognized as pollen grains. Whereas the existence of gymnosperms during the Carboniferous is certain, there is, thus, some possibility that their genesis fell slightly earlier. 
Origin of the angiosperms

Another important subject is the origin of the angiosperms. On the basis of macrofossils it is known that angiospermous plants existed during the Cretaceous. However, these angiosperms belonged to families and genera which still exist today. This is an indication that angiospermous plants already were present prior to the Cretaceous. No macrofossils have, up to now, been discovered which can doubtless prove this, although leaf remains have been described which are assumed by their authors to be of angiospermous origin, and PluMSTEAD (1962) described doubtful angiospermous fructifications from the Lower Permian of South Africa.

An interesting sporomorph from pre-Cretaceous beds which has been thought to be of angiospermous affinity, is the form genus Eucommiidites ERDTMAN, 1948. However, pollen grains of Eucommiidites found in the micropylar canal or in the pollen chamber of two related species of doubtless gymnospermous plants (Hughes, 1961; Brenner, 1967) have disqualified this genus as possible evidence for the existence of pre-Cretaceous angiosperms.

A thing that remains certain is that true angiospermous pollen grains do occur in lowermost Cretaceous deposits. And it is most likely that some of the various studies now in progress on Upper Jurassic material will in the near future produce new evidence for the pre-Cretaceous occurrence of angiosperms. If this is going to happen, palynology might also be able to assist in determining which are the most primitive angiospermous plants.

\section{Origin of the chlamydosperms}

The Chlamydospermae, which morphologically and on the basis of their alternation of generations take an intermediary position between the gymnosperms and angiosperms, are, on the basis of scarce macrofossil remains, not known from older than Tertiary deposits. This might suggest that they originated later than the angiosperms. Palynological studies (e.g., JANSonius, 1962), however, have revealed the existence of chlamydosperms at the end of the Permian or early in the Triassic Period.

\section{MICROPLANKTON}

If one accepts that the field of palynology also comprises the study of other microfossils that remain when samples of fossil pollen and spores are prepared, one feels justified to say at this place a few words about fossil microplankton of botanical affinity also. 


\section{Primary producers in the course of geological time}

The major constituents of Recent phytoplankton are, in order of abundance, diatoms, dinoflagellates, and coccolithophores. Together with naked green flagellates or non-motile cells, these are taken together under the name of "nannoplankton," which is the primary producer in the sea. Although diatoms are known from the Liassic onward, at first they slowly increased in numbers and only became abundant in the Late Cretaceous. Dinoflagellates are mainly a Mesozoic and Cenozoic group, although recently they have also been reported from the Permian (Jansonius, 1962; TASCH, 1963) and the Silurian (CALANdra, 1964). Coccolithophores are widespread and abundant from the Jurassic onward.

During the Mesozoic, when the diatom primacy was only established towards the end, dinoflagellates and coccolithophores, in that order, presumably were responsible for the main primary production in the seas. The succession of the dinoflagellates by the diatoms as number one primary producers, about 70 million years ago, may have been connected with the time of the great dying, which BRAMLETTE (1965) explained from the abnormally-low Mesozoic erosion and the consequent decreased supply of detritus to the seas of Late Cretaceous time. This may have caused "widespread threshold effects on most of the phytoplankton". The disastrous extinction of nannoplankton, which occupied such a vital place in the food chain, led, in its turn, to the extinction of various groups of marine invertebrates (e.g., rudistids, belemnites, ammonites).

During the Palaeozoic, only the dinoflagellates were undoubtedly present. Only some fossil remains have thusfar been reported from that era, but they may have been more widespread in that era than the fossil record suggests ( $\mathrm{TASCH}_{\mathrm{S}}$ 1967). Also present were other unicellular Algae (acritarchs), which also already existed during the Late Precambrian, and which likely have been main primary producers until the end of the Palaeozoic (DownIE, 1967).

It appears from this summary that the main stages in plankton evolution correspond closely to those in the main fossil record (for further details, see DowNIE, 1967). This correspondence is inexplicable. The factors controlling plankton evolution are not yet understood.

\section{Acritarcha}

A review of the present status of knowledge about the acritarchs can be found in Downie (1967).

Precambrian acritarchs belong almost exclusively to the subgroup Sphaeromorphitae. Since records of Radiolaria from the Precambrian have been dismissed (DeflandRe, 1950), the microplankton record of that time consists exclusively of acritarchs. At the beginning of the Palaeozoic, the acritarchs did not immediately show an increase in numbers of species. Not until the Middle Cambrian 
was reached, did a great variety of Diacromorphitae and Acanthomorphitae occur, in addition to the Sphaeromorphitae. Other acritarch subgroups followed at the very end of the Cambrian and in the Ordovician and Silurian. The Carboniferous shows a most notable reduction in the number of acritarch species. In that period and in the Permian, small forms constitute almost all of the plankton. Although the Palaeozoic acritarchs show some similarities with living Algae, no cogent argument exists to taxonomically include any substantial part of these acritarchs in any particular class of Recent Algae.

\section{Rise of dinoflagellates}

BERKNer and Marshall (1965) have set forth a most interesting theory on the evolution of oxygen in the earth's atmosphere. In recent years it has become almost certain that the early atmosphere lacked free oxygen (Holland, 1962). Production of free oxygen started when photosynthesis began, probably more than $2.7 \cdot 10^{9}$ years ago. Berkner and Marshall proposed that the beginning of Cambrian time marks the attainment of the "Pasteur point" in the atmosphere $(1 \%$ present atmospheric level, PAL). They believe that animal life before that time was of a very low and primitive sort. At $1 \%$ PAL, however, organisms should have been able to change from fermentation to respiration (cf. also RutTen, 1966).

Fischer (1965) endorsed the views of Berkner and Marshall. He assumed the Precambrian animals initially developed in strongly isolated communities, limited to "oxygen oases" of individual plant patches. At $1 \%$ PAL these animals could leave the host plants and move towards the air-water interface; photosynthetic Algae were incorporated in their tissues, in zoochlorellar or zooxanthellar symbiosis, as an internal oxygen supply. The true emancipation of animals came when oxygen over wide areas of the ocean rose to levels capable of supporting oxidizing respiration.

Several investigators (cf. YounGe, 1957, pp. 431-432) considered modern Zooxanthellae, as these occur in, e.g., the tissues of corals, as the immotile stage of a dinoflagellate. If clearcut affinities could be shown, a previously unrecognized Precambrian-Cambrian role for the immotile stage of one or more dinoflagellates would be indicated (TASCH, 1967) and the origin of that group of organisms would be much easier to understand.

\section{Importance of dinoflagellate cysts for stratigraphy}

Particularly since the beginning of the nineteen-sixties, the number of published studies dealing with dinoflagellate cysts has increased enormously. They revealed the rapidity of changes in dinoflagellate-cyst assemblages. The available information regarding the stratigraphical distribution of fossil dinoflagellate remains was recently summarized by SARJEANT (1967). His tables clearly demonstrate the value of these fossils as stratigraphical indices in marine sediments of Mesozoic and Tertiary age. 


\section{CONCLUDING REMARKS}

Palynology is a rapidly developing field of science with many enthusiastic researchers and a continuous production of interesting new scientific information. Only a very small selection of recent data could be discussed in this paper. My apologies go towards all those workers whose contributions to palynology could not be mentioned in the pages available.

\section{REFERENCES}

Abramova, S. A. and Marchenko, O. F., 1964a. Some additional material concerning the palynology of the subsalinary series of the Kungurian of the Verchnekamskaia deposit (boring 179). Tr. Vses. Nauchn. Issled. Inst. Galurgii, 45: 117-122 (in Russian).

Abramova, S. A. and Marchenko, O. F., 1964b. Experiment in the use of the palynological method of research in the study of salt domes in the area of the Caspian Sea. Tr. Vses. Nauchn. Issled. Inst. Galurgii, 45: 122-137 (in Russian).

Abramova, S. A. and MarCHENKo, O. F., 1964c. Results of a palynological investigation of salt deposits of the Kungurian Beds of the Verchnekamskaia deposit. Tr. Vses. Nauchn. Issled. Inst. Galurgii, 45: 75-116 (in Russian).

Alpern, B., LachKar, G. et LiabeuF, J. J., 1967. Le bassin houiller Lorrain peut-il fournier un stratotype pour le Westphalien supérieur? Rev. Palaeobotan. Palynol., 5: in press.

ANDERSEN, S. TH., 1967. Tree pollen rain in a mixed deciduous forest in south Jutland (Denmark). Rev. Palaeobotan. Palynol., 3: in press.

Arrhenius, G., 1952. Sediment cores from the eastern Pacific. Swed. Deep-Sea Expedition, 1947-1948, 5(1): 6-227.

Baltes, N., 1967. Microflora from Miocene salt-bearing formations of the pre-Carpathian depression (Rumania). Rev. Palaeobotan. Palynol., 2: in press.

Berger, F., 1934. Das Verhalten der Heufieber erregender Pollen im filtrierten ultra-violetten Licht. Beitr. Biol. Pflanzen, 22(1): 1-12.

Berkner, L. V. and Marshall, L. C., 1965. The history of growth of oxygen in the earth's atmosphere. In: P. S. Brancazio and A. G. W. Cameron (Editors), The Origin and Evolution of Atmospheres and Oceans. Wiley, New York, N.Y., pp. 86-101.

Bottema, S. and Van StraAten, L. M. J. U., 1966. Malacology and palynology of two cores from the Adriatic Sea floor. Marine Geol., 4(6): 553-564.

Boulouard, C. et Delauze, H., 1966. Analyse palynoplanctologique de sédiments prélevés par le bathyscaphe "Archimède" dans la fosse du Japon. Marine Geol., 4(6): 461-466.

Bramlette, W. N., 1965. Massive extinctions in biota at the end of Mesozoic time. Science, 148: $1696-1699$.

Brenner, G. J., 1967. The gymnospermous affinity of Eucommiidites ErdtMan. Rev. Palaeobotan. Palynol., 5: in press.

Bucher, W. H., 1964. The third confrontation. In: A. E. M. NAIRN (Editor), Problems in Palaeoclimatology. Interscience, London, pp. 3-9.

Calandra, F., 1964. Sur une présumé dinoflagellé Arpylorus nov, gen. du Gothlandien de Tunisie. Compt. Rend., 258: 4112-4114.

Chaloner, W. G., 1967. Spores and land-plant evolution. Rev. Palaeobotan. Palynol., 1: 83-93.

Cross, A. T., Thompson, G. G. and ZaitzefF, J. B., 1966. Source and distribution of palynomorphs in bottom sediments, southern part of Gulf of California. Marine Geol., 4(6): $467-524$.

CUSHING, E. J., 1967. Evidence for differential pollen preservation in Late Quaternary sediments in Minnesota. Rev. Palaeobotan. Palynol., 4: in press. 
Davis, M. B., 1967. Pollen accumulation rates at Rogers Lake, Connecticut, during Late and Postglacial time. Rev. Palaeobotan. Palynol, 2: in press.

Deflandre, G., 1950. Les soi-disant radiolaires du Précambrien de Bretagne et la question de l'existence de radiolaires embryonnaires fossiles. Congr. Intern. Zool., I3ème, Paris, 1948-Bull. Soc. Zool. France, 74: 351-352.

DownIE, C., 1967. The geological history of the microplankton. Rev. Palaeobotan. Palynol., 1: 269-281.

Dyakowska, J., 1948. The pollen rain on the sea and on the coasts of Greenland. Bull. Acad. Polon. Sci. Lett., Cl. Sci. Math. Nat., Sér. B, 1:25-33.

ERdtman, G., 1943. An Introduction to Pollen Analysis. Chronica Botanica Co., Waltham, Mass., $239 \mathrm{pp}$.

Erdtman, G., 1954. An Introduction to Pollen Analysis. Chronica Botanica Co., Waltham, Mass., 2 ed., 239 pp.

FAeGri, K. and IverSen, J., 1964. Textbook of Pollen Analysis. Munksgaard, Copenhagen/Blackwell, Oxford, 2 ed., 237 pp.

Fedorova, R. V., 1952. Dissémination des pollen et des spores par les eaux courantes. Traveaux Inst. Géogr. (Acad. Sci. U.S.S.R.), 52 (Données sur la géomorphologie et la paléogéographie d'U.R.S.S., Acad. Sci. U.S.S.R., 7): 46-52.

Fischer, A. G., 1965. Fossils, early life, and atmospheric history. Proc. Natl. Acad. Sci. U.S., 53(6): 1205-1215.

Freudenthal, T., 1964. Palynology of Lower Triassic rock salt, Hengelo, The Netherlands. Acta Botan. Neerl., 13: 209-236.

Glaessner, M. F., 1966. Precambrian palaeontology. Earth-Sci. Rev., 1(1): $29-50$.

Groot, J. J., 1963. Palynological investigations of a core from the Biscay Abyssal Plain. Science, 141: 522-523.

Groot, J. J., 1966. Some observations on pollen grains in suspension in the estuary of the Delaware River. Marine Geol., 4(6): 409-416.

Groot, J. J. and Groot, C. R., 1964. Quaternary stratigraphy of sediments of the Argentine Basin. Trans. N.Y. Acad. Sci., Ser. II, 26: 881-886.

Groot, J. J. and Groot, C. R., 1966a. Marine palynology: possibilities, limitations, problems. Marine Geol., 4(6): 387-395.

Groot, J. J. and Groot, C. R., 1966b. Pollen spectra from deep-sea sediments as indicators of climatic changes in southern South America. Marine Geol., 4(6): 525-537.

Groot, J. J. and Groot, C. R., in preparation. Palynology of sediments off the coast of central Chile.

Groot, J. J., Groot, C. R., Ewing, M., Burckle, L. and Conally, J. R., in press. Spores, pollen, diatoms and provenance of the Argentine Basin sediments. Symposium on the Quaternary History of the Ocean Basins.

Gutjahr, C. C. M., 1966. Carbonization measurements of pollen grains and spores and their application. Leidse Geol. Mededel., 38: 1-29.

Havinga, A. J., 1962. Een Palynologisch Onderzoek van in Dekzand Ontwikkelde Bodemprofielen. Thesis, Agricultural Univ., Wageningen, $165 \mathrm{pp}$.

HAVINGA, A. J., 1964. Investigations into the differential corrosion susceptibility of pollen and spores. Pollen Spores, 6(2): 621-635.

Having A, A. J., 1967. Palynology and pollen preservation. Rev. Palaeobotan. Palynol., 3: in press.

Hesselmann, H., 1919. Über die Verbreitungsfähigkeit des Waldbaumpollens. Medd. Statens Skogsforsöksanstalt, Stockholm.

HiLL, D., 1957. The sequence and distribution of Upper Palaeozoic coral faunas. Australian J. Sci., 19: 42-61.

Holland, H. D., 1962. Model for the evolution of the earth's atmosphere. In: A. E. J. ENGEL, H. L. James and B. Leonard (Editors), Petrologic Studies: A Volume to Honor A.F. Buddington. Geol. Soc. Am., New York, N.Y., pp. 447-477.

Hopping, C., 1967. Palynology and the oil industry. Rev. Palaeobotan. Palynol., 2: in press.

Hughes, N. F., 1961. Further interpretation of Eucommiidites ERdTMAN, 1948. Palaeontology, 4(2): 292-299. 
Hughes, N. F. and Moody-Stuart, J. C., 1967. Proposed method of recording pre-Quaternary palynological data. Rev. Palaeobotan. Palynol., 3: in press.

Iversen, J. og TroëLs-Smith, J., 1950. Pollenmorfologiske definitioner og typer. Danmarks Geol. Undersogelse, IV, 3(8): 1-53.

Jansonius, J., 1962. Palynology of Permian and Triassic sediments, Peace River area, western Canada. Palaeontographica, B, 110:35-98.

Jux, U., 1961. The palynologic age of diapiric and bedded salt in the Gulf Coastal Province. Louisiana Dept. Conserv., Geol. Bull., 38: 1-46.

Kirchheimer, F., 1933a. Die Erhaltung der Sporen und Pollenkörner in den Kohlen sowie ihre Veränderungen durch die Aufbereitung. Botan. Arch., 35: 134-187.

KirchHeimer, F., 1933b. Der Erhaltungszustand des Pollens in den Glanzbraunkohlen. Ber. Schweiz. Botan. Ges., 42: 246-251.

KirchHeIMER, F., 1934. Die Bodenbeschaffenheit unter erhöhtem Druck thermisch beanspruchter Lycopodium Sporen. Ber. Schweiz. Botan. Ges., 43: 19-29.

Kirchheimer, F., 1935. Die Korrosion des Pollens. Botan. Centr., Beih., A53: 389-416.

KirchHeimer, F., 1950. Mikrofossilien aus Salzablagerungen des Tertiärs. Palaeontographica, B, 90: $127-160$.

KLaus, W., 1953a. Mikrosporen-Stratigraphie der ostalpinen Salzgebirge. Verhandl. Geol. Bundesanstalt (Austria), 3:161-175.

KLaus, W., 1953b. Alpine Salzmikropaläontologie (Sporendiagnose). Paläontol. Z., 27: 52-56.

Klaus, W., 1954. Palynology of salt. Huitième Congrès Intern. Botan., Paris 1954, Compt. Rend. Séances et Rapport et Communications déposés lors du Congrès dans les Sections $3,4,5$ et 6 , pp. 253-254.

KLaus, W., 1955. Über die Sporendiagnose des deutschen Zechsteinsalzes und des alpinen Salzgebirges. Z. Deut. Geol. Ges., 105: 776-788.

KLaus, W., 1958. Some Lower Mesophytic microspores of Europe with remarks on their relation to the Gondwana microflora. J. Palaeontol. Soc. India, 3: 151-155.

Klaus, W., 1960. Sporen der karnischen Stufe der ostalpinen Trias. Jahrb. Geol. Bundesanstalt (Austria), Sonderber., 5: 107-183.

Klaus, W., 1963a. Sporen aus dem südalpinen Perm. Jahrb. Geol. Bundesanstalt (Austria), 106: 229-363.

Klaus, W., 1963b. In: B. Plöchinger, Exkursionen in den Grünbach-Graben am Untersberg-Ostfluss (Salzburg). Verhandl. Geol. Bundesanstalt (Austria), Sonderh., F: 65-67.

KLAUS, W., 1964. Zur sporen-stratigraphischen Einstufung von gipsführenden Schichten in Bohrungen. Erdöl Z., 4: 119-132.

Klaus, W., 1965a. Zur Einstufung alpiner Salztone mittels Sporen. Verhandl. Geol. Bundesanstalt (Austria), Sonderh., G: 288-292.

KLaus, W., 1965b. Pterocarya-Pollen im Quartär-Salz aus Israel. Pollen Spores, 7(3): 529-531.

Koreneva, E. V., 1957. Spore-pollen analysis of bottom sediments from the Sea of Okhotsk. Tr. Inst. Okeanol. Akad. Nauk S.S.S.R., 22: 221-251 (in Russian).

KORENEVA, E. V., 1961. Research according to the method of spore-pollen analysis of two cores of marine sediments from the Japanese Sea. Okeanologiya, 1(4): 651-657 (in Russian).

KoreneVA, E. V., 1964. Distribution of spores and pollen of terrestrial plants in bottom sediments of the Pacific Ocean. In: L. M. Cranwell (Editor), Ancient Pacific Floras: The Pollen Story. Univ. Hawaii Press, Honolulu, Hawaii, p.31.

KoreneVA, E. V., 1966. Marine palynological researches in the U.S.S.R. Marine Geol., 4(6): $565-574$.

LARSSON, G., 1948. Examination of pollen grains in three cores from the Tyrrhenian Sea. In: H. Petterson (Editor), Three Sediment Cores from the Tyrrhenian Sea. Göteborg Kgl. Vetensk. Vitterhets-Samh. Handl. f 6, Ser. B, 5(13): 73-79.

LeschiK, G., 1956. Sporen aus dem Salzton des Zechsteins von Neuhof bei Fulda. Palaeontographica, $B, 100: 122-142$.

Levelt, TH. W. M., 1965. Die Plateaulehme Süd-Luxemburgs und ihre Bedeutung für die morphogenetische Interpretation der Landschaft. Veröffentl. Luxemburger Geol. Dienstes, 15: $1-215$. 
Lotze, F., 1964. The distribution of evaporites in space and time. In: A. E. M. NAIRN (Editor), Problems in Palaeoclimatology. Interscience, London, pp. 491-507.

Lubliner-MianowsKa, K., 1962. Pollen analysis of the surface samples of bottom sediments in the Bay of Gdansk. Acta Soc. Botan. Polon., 31: 305 -312.

Mal, D. H., 1964. Die Mastixioideen-Floren im Tertiär der Oberlausitz. Paläontol. Abhandl. Geol. Ges. D.D.R., B, 2: 1-192.

MAI, D. H., 1965. Der Florenwechsel im jüngeren Tertiär Mitteleuropas. Feddes Repertorium, 70: 157-169.

MaIER, D., 1959. Planktonuntersuchungen in tertiären und quartären marinen Sedimenten. Neues Jahrb. Geol. Paläontol., Abhandl., 107(3): 298-299.

MAIER, D. und WETZEL, W., 1958. Fluoreszenzmikroskopie geologischer und paläontologischer Objekte. Zeiss Mitt., 1(4): 127-131.

Manten, A. A., 1966a. Microfossil-like objects in meteorites. Earth-Sci. Rev., 1(4): 337-341.

Manten, A. A., 1966b. Half a century of modern palynology. Earth-Sci. Rev., 2(4): 277-316.

Muller, J., 1959. Palynology of Recent Orinoco delta and shelf sediments. Micropaleontology, 5: $1-32$.

Neustadt, M. I., Hotinskiy, N. A., Dervic, A. L. and Markova, N. G., 1965. The Imnatskoye swamp (Georgian S.S.R.). In: M. I. Neustadt (M. I. NejShstadt) (Editor), Palaeogeography and Chronology of the Upper Pleistocene and the Holocene according to the Radiocarbon Method (Volume prepared for the 7th INQUA Congress, U.S.A., 1965). Nauka, Moscow, pp.105-112 (in Russian).

Panov, D. G., Vronskiy, V. A. and Aleksandrov, A. N., 1964. Distribution and composition of pollen and spores in the surface layer of sediments on the Sea of Azov. Dokl. Akad. Nauk S.S.S.R., 154(4): 818-821 (in Russian).

Plumstead, E. P., 1962. Possible angiosperms from Lower Permian coal of the Transvaal. Nature, 194(4828): 594-595.

PotoniÉ, R. und Klaus, W., 1954. Einige Sporengattungen des alpinen Salzgebirges. Geol. Jahrb., 68: 517-546.

Rossignol, M., 1961. Analyse pollinique de sédiments marins quaternaires en Israel, 1. Sédiments récents. Pollen Spores, 3: 303-324.

Rossignol, M., 1962. Analyse pollinique de sédiments marins quaternaires en Israel, 2. Sédiments pleistocènes. Pollen Spores, 4(1): 121-148.

Rutten, M. G., 1966. Geologic data on atmospheric history. Palaeogeography, Palaeoclimatol., Palaeoecol., 2(1): 47-57.

Sarjeant, W. A. S., 1967. The stratigraphical distribution of fossil dinoflagellates. Rev. Palaeobotan. Palynol., 1: 323-343.

Shaffer, B. L., 1961. Microfloral successions in Middle Permian evaporites of Kansas. Geol. Soc. Am., Program Ann. Meeting, 1961: 143A (abstract).

ShafFer, B. L., 1964. Stratigraphic and paleoecologic significance of plant microfossils in Permian evaporites of Kansas. In: A. T. Cross (Editor), Palynology in Oil Exploration-Soc. Econ. Paleontologists Mineralogists, Spec. Publ., 11: 97-115.

Sittler, C., 1967. Mise en évidence d'un réchauffement climatique à la limite de l'Oligocène et du Miocène. Rev. Palaeobotan. Palynol., 2: in press.

STANLEY, E. A., 1965a. The use of reworked pollen and spores for determining the PleistoceneRecent and the intra-Pleistocene boundaries. Nature, 206: 289-291.

STANLEY, E. A., 1965b. Abundance of pollen and spores in marine sediments off the eastern coast of the United States. Southeastern Geol., 7(1):25-33.

STANLeY, E. A., 1966a. The application of palynology to oceanology with reference to the northwestern Atlantic. Deep-Sea Res., 13(5): 921-939.

STANLEY, E. A., 1966b. The problem of reworked pollen and spores in marine sediments. Marine Geol., 4(6): 397-408.

Stanley, E. A., 1967. Palynology of six ocean-bottom cores from the southwestern Atlantic Ocean. Rev. Palaeobotan. Palynol., 2: in press.

Sullivan, H. J., 1965. Palynological evidence concerning the regional differentiation of Upper Mississippian floras. Pollen Spores, 7(3): 539-563. 
Sullivan, H. J., 1967. Regional differences in Mississippian spore assemblages. Rev. Palaeobotan. Palynol., 1: 185-192.

Tasch, P., 1963. Hystrichosphaerids and dinoflagellates from the Permian of Kansas. Micropaleontology, 9(3): 332-336.

TASCH, P., 1967. The problem of primary production in the seas through geologic time. Rev. Palaeobotan. Palynol., 1: 283-290.

TAUBER, H., 1965. Differential pollen dispersal and the interpretation of pollen diagrams. Danmarks Geol. Undersøgelse, II, 89: 1-69.

Traverse, A. and Ginsburg, R. N., 1966. Palynology of the surface sediments of Great Bahama Bank, as related to water movement and sedimentation. Marine Geol., 4(6): 417-459.

Traverse, A. and Ginsburg, R. N., 1967. Pollen and associated microfossils in the marine surface sediments of the Great Bahama Bank. Rev. Palaeobotan. Palynol., 3: in press.

VAN GiJzel, P., 1961. Autofluorescence and age of some fossil pollen and spores. Koninkl. Ned. Akad. Wetenschap., Proc., Ser. B, 64(1): 56-63.

VAN GuJzel, P., 1963. Notes on autofluorescence of some Cenozoic pollen and spores from The Netherlands. Mededel. Geol. Sticht., N. Ser., 16: 25-32.

Van GiJzel, P., 1966. Die Fluoreszenz-Photometrie von Mikrofossilien mit dem zweistrah1Mikroskopphotometer nach Berek. Leitz Mitt. Wiss. Tech., 3(7): 206-214.

Van GiJzel, P., 1967a. Palynology and fluorescence microscopy. Rev. Palaeobotan. Palynol., 2: in press.

VAN GiJzel, P., 1967b. Autofluorescence of fossil pollen and spores with special reference to age determination and coalification. Leidse Geol. Mededel., 39: in preparation.

Van Veen, F. R., 1958. Pollen from the South China Sea. Serawak Museum J., 8(11): 351-356.

VAN ZeIST, W., 1967. Archaeology and palynology in The Netherlands. Rev. Palaeobotan. Palynol., 4: in press.

Varencov, M. I., Ditmar, V. I., Li, A. B., and others, 1964. Age du sel gemme dans les structures de diapir de la dépression de Chu-Saryui. Dokl. Akad. Nauk S.S.S.R., 159: 327-329.

VISSCHER, H., 1966. Palaeobotany of the Mesophytic, 3. Plant microfossils from the Upper Bunter of Hengelo, The Netherlands. Acta Botan. Neerl., 15: 316-375.

VISSCher, H., 1967. Permian and Triassic palynology and the concept of "Tethys twist". Palaeogeography, Palaeoclimatol., Palaeoecol., 3(1): in press.

VON DER BRELIE, G., 1967. Quantitative Sporenuntersuchungen zur stratigraphischen Gliederung des Neogens in Mitteleuropa. Rev. Palaeobotan. Palynol., 2: in press.

Von Post, L., 1916. Om skogsträdpollen i sydsvenska torfmosselager följder. Geol. Fören. Stockholm Förh., 38: 384-390, 392-393.

Vronskiy, V. A. and Panov, D. G., 1963. Composition and distribution of pollen and spores in the surface layer of marine sediments in the Mediterranean Sea. Dokl. Akad. Nauk S.S.S.R., 153(2): 447-449 (in Russian).

WeTZeL, W., 1959. Das lumineszenzmikroskopische Verhalten von Sedimenten. Neues Jahrb. Geol. Paläontol., Abhandl., 107(3): 261-277.

Wilson, L. R., 1961. Palynological fossil response to low-grade metamorphism in the Arkoma Basin. Tulsa Geol. Soc. Dig., 29: 131-140.

WiLSON, L. R., 1964. Recycling, stratigraphic leakage, and faulty techniques in palynology. Grana Palynologica, 5(3): 425-436.

WiLson, L. R., 1967. Palynological evidence for folding, faulting and erosional contacts in subsurface. Rev. Palaeobotan. Palynol., 1:65 (abstract).

Wright, JR., H. E., 1967. The use of surface samples in Quaternary pollen analysis. Rev. Palaeobotan. Palynol., 2: in press.

Younge, C. M., 1957. Symbiosis. In: J. W. HedGPETH (Editor), Treatise on Marine Ecology and Paleoecology, 1. Ecology. Geol. Soc. Am., Mem., 67: 429-442.

ZaGwiJn, W. H. and Veenstra, H. J., 1966. A pollen-analytical study of cores from the Outer Silver Pit, North Sea. Marine Geol., 4(6): 539-551. 